DOI: 10.17707/AgricultForest.62.2.16

\author{
Danka CAKOVIĆ, Danijela STEŠEVIĆ, \\ Ana TOPALOVIĆ, Mirko KNEŽEVIĆ ${ }^{1}$
}

\title{
EFFECT OF DIFFERENT FERTILIZATION REGIMES ON THE WEED COMMUNITY IN SWISS CHARD
}

\begin{abstract}
SUMMARY
Weed community of Swiss chard was studied in plots with different fertilization regimes. Fertilization doses correspond to 50\% (F50), 100\% (F100) and 150\% (F150) nutrient demand of Swiss chard. Sinousia consists of 29 species, out of 26 genera and 17 families, among which dominant are: Sorghum halepense, Solanum nigrum, Kickxia spuria, and Atriplex patula. The analysis of the biological spectrum indicates the dominance of therophytes with $75.8 \%$, while hemicryptophytes contribute the spectrum with $17.2 \%$. Considering the effect of fertilizers on the crop growth and weediness, general conclusion is that fertilizers benefit both the crop and weeds, but increased doses of fertilizers had better effect on the crop yield than on weediness. The average crop yield was highest in the regime F150, as well as total weediness F150. However, analysing the species abundance, cover per single plot and crop yield in each regime of fertilization, some deviations are noticed. Such as, in the plots No 10 (belongs to F100) and No 17 (belongs to F150) the total weed cover was 10\%. In eight plots which belongs to F50 the weed cover exceeded this value.
\end{abstract}

Keywords: weed community, fertilization, Swiss chard

\section{INTRODUCTION}

Fertilisation is considered as one of the powerful tools in managing weeds (Liebman and Mohler, 2001), with precondition of exact choise of time and way of application of the fertilizers (Blackshaw et. al., 2004). In general, process of fertilization increases total biomas production in filed, but not exclusively crop production. Some studies shown that weeds might be more effective than crops in capturing nutrients added as fertilizers (Santos et al., 1998; Blackshaw et al., 2003), while in others crops are more effective (Dusky et al., 1996; Dhima and Eleftherohorinos, 2001).

Alhtough in Mediterraena cuisine Swiss chard is frequently used, in the global market it is treated as one of the neglected vegetable species, which production area is not commercially important (Pokluda and Kuben, 2002). Similar situation is present in Montenegro. The crop is grown only in Zetsko-

\footnotetext{
${ }^{1}$ Danka Caković (corresponding author: danka.petrovic@t-com.me), Danijela Stešević, , University of Montenegro, Faculty of Natural Sciences and Mathematics, Department of Biology, Ana Topalović, Mirko Knežević , University of Montenegro, Biotechnical Faculty, Center for Soil and Melioration.MONTENEGRO

Notes: The authors declare that they have no conflicts of interest. Authorship Form signed online.
} 
Bjelopavlićka plain on rather small areas and mostly distributed in the southern part of the country, where the tradition in its consumption still exists (Knežević et al., unpublished data).Taking into account its good nutritional values (Santamaria et al., 1999a, 1999b) and medicinal properties - the extract of this plant when administered by gavage may reduce blood glucose levels by regeneration of the B cells (Bolkenta et al., 2000), its production might increase in the future. Up to know research on Swiss chardwere focused on morphological characteristics, yield, content of mineral elements and nutritional quality (Malý et al., 1998; Santamaria et al., 1999a, 1999b; Pokluda and Kuben, 2002; Smith et al., 2001; Miceli and Miceli, 2001), salt tolerance (Shannon et al., 2000), while weed research were rather neglected. The aim of this research is to determine the dynamics of weed infestation in Swiss chard cultivated in crop rotation with different levels of mineral fertilizing.

\section{MATERIAL AND METHODS}

The Swiss chard was grown in the field of Green House Jovović company, in Bjelopavlićka Plain, site Sige $\left(42.553191^{\circ} \mathrm{N}\right.$ latitude and $19.149113^{\circ} \mathrm{E}$ longitude). The soil is intesively used for vegetable production, has high content of total carbonate and alkaline reaction (Knežević et al, 2014). The results of soil analysis (samples taken before fertilization) are shown in Table 1.

An experiment with randomized design was conducted in the period March-July 2014. The experimental field contained 28 plots - nine plots treated with three different level of fertilization (labelled as F50, F100 and F150) and one control plot without fertilization and irrigation (C). Plot area was $10.5 \mathrm{~m}^{2}$. Fertilization doses corresponded to $50 \%, 100 \%$, and $150 \%$ of commercial recomendations for Swiss chard, which were $100-120 \mathrm{~kg} / \mathrm{ha} \mathrm{N}, 80-120 \mathrm{~kg} / \mathrm{ha}$ $\mathrm{P}_{2} \mathrm{O}_{5}$, and $100 \mathrm{~kg} / \mathrm{ha} \mathrm{K}_{2} \mathrm{O}$ per season. Fertilization amounts of NPK fertilizer 11:11:21 were $200 \mathrm{~kg} / \mathrm{ha}, 400 \mathrm{~kg} / \mathrm{ha}$, and $600 \mathrm{~kg} / \mathrm{ha}$. Additional nutrient fertilization, in amounts $35 \mathrm{~kg} / \mathrm{ha}, 70 \mathrm{~kg} / \mathrm{ha}$, and $105 \mathrm{~kg} / \mathrm{ha}$ for various treatments, was applied by watering with the same volume of appropriate solution twice during vegetation. The solution was prepared by dissolving of NPK 24:8:16 and NPK 15:30:15 in ratio 2:1. Irrigation amount of $60 \mathrm{~mm}$ of water was applied uniformly at all plots, excluding control plot, during the season.

The investigation of the weed community was carried out in the second half of May and early June 2014. Herbicides were not used in this period. In each plot all weed species, weed density (number of individuals per $\mathrm{m}^{2}$ ), the cover of single weed species and total weed cover were recorded.The cover is estimated with original cover-abundance scale of Braun-Blanquet extended to a combined cover-abuncance scale by Barkman et al. (1964). Total weed cover is given in percents (\%). Weed species were identified by Domac (1994). Life form classification is performed according to Raunkier, elaborated and updated by Ellenberg and Mueller-Dombois (1967) and, for our circumstances, modified by Stevanović (1992). 
Table 1. Soil parameters (before fertilization)

\begin{tabular}{|c|c|c|c|c|c|c|c|c|}
\hline $\begin{array}{c}\text { Label of } \\
\text { plot }\end{array}$ & $\begin{array}{c}\mathrm{pH} \\
\left(\mathrm{H}_{2} \mathrm{O}\right)\end{array}$ & $\begin{array}{c}\mathrm{pH} \\
(\mathrm{KCl})\end{array}$ & $\begin{array}{c}\mathrm{CaCO}_{3} \\
(\%)\end{array}$ & $\begin{array}{c}\text { Total N } \\
(\%)\end{array}$ & $\begin{array}{c}\text { Humus } \\
(\%)\end{array}$ & $\begin{array}{c}\text { Available } \\
\mathrm{P}_{2} \mathrm{O}_{5} \\
(\mathrm{mg} / 100 \mathrm{~g})\end{array}$ & $\begin{array}{c}\text { Available } \\
\left.\mathrm{K}_{2} \mathrm{O} / 100 \mathrm{~g}\right)\end{array}$ & $\begin{array}{c}\mathrm{EC} \\
(\mu \mathrm{S} / \mathrm{cm})\end{array}$ \\
\hline 1F100 & 7.60 & 7.04 & 3.3 & 0.278 & 5.89 & 6.2 & 23.0 & 155.0 \\
\hline 2F50 & 7.55 & 7.02 & 2.8 & 0.263 & 6.10 & 4.9 & 22.0 & 158.2 \\
\hline 3F100 & 7.70 & 7.17 & 2.3 & 0.252 & 5.74 & 4.2 & 23.4 & 158.8 \\
\hline 4F100 & 7.70 & 7.20 & 4.7 & 0.248 & 5.50 & 3.8 & 20.6 & 145.8 \\
\hline 5F50 & 7.70 & 7.21 & 21.4 & 0.254 & 5.77 & 5.0 & 21.3 & 156.1 \\
\hline 6F150 & 7.77 & 7.25 & 21.9 & 0.236 & 5.21 & 6.8 & 19.9 & 146.0 \\
\hline 7F150 & 7.76 & 7.27 & 10.9 & 0.255 & 5.95 & 5.3 & 23.0 & 167.9 \\
\hline 8F150 & 7.88 & 7.35 & 21.4 & 0.245 & 6.10 & 5.8 & 22.3 & 163.3 \\
\hline 9F50 & 7.91 & 7.35 & 6.7 & 0.236 & 5.86 & 3.8 & 21.8 & 150.3 \\
\hline 10F100 & 7.93 & 7.34 & 21.9 & 0.228 & 5.95 & 9.4 & 18.7 & 150.7 \\
\hline 11F50 & 7.90 & 7.32 & 21.9 & 0.222 & 5.06 & 20.1 & 18.7 & 150.1 \\
\hline 12F100 & 7.87 & 7.31 & 23.8 & 0.216 & 4.91 & 21.6 & 16.2 & 145.4 \\
\hline 13F100 & 7.95 & 7.38 & 26.2 & 0.206 & 4.94 & 16.6 & 19.2 & 155.4 \\
\hline 14C & 7.94 & 7.40 & 26.2 & 0.216 & 4.73 & 7.6 & 20.4 & 153.4 \\
\hline 15F50 & 7.79 & 7.20 & 3.8 & 0.280 & 6.25 & 7.9 & 32.7 & 158.8 \\
\hline 16F150 & 7.77 & 7.23 & 2.8 & 0.291 & 6.19 & 11.6 & 32.7 & 157.4 \\
\hline 17F150 & 7.77 & 7.27 & 3.3 & 0.284 & 6.01 & 12.5 & 30.4 & 152.4 \\
\hline 18F150 & 7.75 & 7.28 & 4.7 & 0.285 & 5.92 & 11.2 & 30.4 & 158.2 \\
\hline 19F50 & 7.93 & 7.35 & 6.7 & 0.284 & 5.53 & 10.3 & 32.7 & 166.3 \\
\hline 20F100 & 7.97 & 7.38 & 11.9 & 0.271 & 5.39 & 8.0 & 23.0 & 157.6 \\
\hline 21F50 & 7.91 & 7.37 & 19.0 & 0.263 & 5.06 & 5.3 & 22.0 & 161.6 \\
\hline 22F100 & 7.90 & 7.41 & 30.9 & 0.237 & 5.15 & 6.1 & 20.6 & 149.5 \\
\hline 23F100 & 7.78 & 7.21 & 38.1 & 0.208 & 4.85 & 8.3 & 19.2 & 154.6 \\
\hline 24F50 & 7.80 & 7.22 & 38.5 & 0.237 & 4.79 & 9.4 & 17.3 & 148.2 \\
\hline 25F150 & 7.91 & 7.35 & 39.0 & 0.229 & 3.50 & 13.8 & 16.9 & 149.1 \\
\hline 26F150 & 7.88 & 7.35 & 35.7 & 0.224 & 2.60 & 18.8 & 17.6 & 154.6 \\
\hline 27F150 & 8.00 & 7.46 & 32.4 & 0.227 & 2.93 & 12.7 & 18.7 & 158.6 \\
\hline 28F50 & 8.00 & 7.48 & 33.3 & 0.227 & 3.05 & 8.2 & 18.5 & 153.7 \\
\hline
\end{tabular}

The descriptive statistical analysis (minimum, maximum, mean and standard deviation) of the data was performed by SPSS.

\section{RESULTS AND DISCUSSION}

\section{Floristic composition and taxonomic spectrum.}

The structure and number of weed species found in the Swiss chard during investigation are shown in Tables 2, 3 and 4. Weed sinousia of Swiss chard in Montenegro consists of 29 species, out of 26 genera and 17 families. Families Poaceae and Scrophulariaceae are dominant and represented with 4 species each, Fabaceae with 3, Asteraceae, Chenopodiaceae, Euphorbiaceae, and Geraniacaae with 2 species each, while others have one representative each. 
Such taxonomical spectrum differs from the one of the sinousia of other crops investigated in Montenegro: i) maize- Poaceae (4 species) Polygonaceae (3 species), Brassicaceae, Chenopodiaceae, and Plantaginaceae (2 species each), Amaranthaceae, Caryophyllaceae, Convolvulaceae, Fabaceae, Lamiaceae, Scrophylariaceae (1 species each) (Jovović, 1998); ii) potato- Asteraceae (8 species), Lamiaceae (5 species), Fabaceae, Poaceae, Polygonaceae (4 species each), Scrophulariaceae (3 species), Brassicaceae, Caryophyllaceae, Chenopodiaceae, Euphorbiaceae (2 species each), Amaranthaceae, Apiaceae, Boraginacea, Convolvulaceae, Equisetaceae, Geraniaceae, Primulaceae, Rosaceae, Rubiaceae, Solanaceae, Violaceae (1 species each) (Stešević and Jovović, 2005). Speaking in the term of dominant species in Swiss chard sinousia the most abundant were Sorghum halepense, Solanum nigrum, Kickxia spuria and Atriplex patula, while in maize crop Chenopodium album, Amaranthus retroflexus and Polygonum aviculare prevailed (Jovović 1998). In the potato crop dominant weeds were Convolvulus arvensis, Anthemis arvensis and Sonchus arvensis (Stešević and Jovović, 2005).

On the plots with treatmen F50 and F150 number of recorded species is 27, while tretment F100 has 26 species. Average number of species per treatment is: C - 15, F50 - 14.7, F100 - 14.1 and F150 - 15.1. The most abundant species in sinousia are Sorghum halepense, Solanum nigrum, Kickxia spuria and Atriplex patula. They comprised $67.3 \%$ of the total weediness. Ranking of dominant species (number of individuals per $\mathrm{m}^{2}$ ) differs between the treatments: in the $\mathrm{C}$ are A. patula $\left(13,3 / \mathrm{m}^{2}\right)$ and $S$. halepense $\left(10,5 / \mathrm{m}^{2}\right)$, in the F50 are $S$. halepense $\left(12,8 / \mathrm{m}^{2}\right), K$. spuria $\left(4,1 / \mathrm{m}^{2}\right)$ and $S$. nigrum $\left(2,6 / \mathrm{m}^{2}\right)$; in the F100 are S. halepense $\left(12,9 / \mathrm{m}^{2}\right), K$. spuria $\left(3,8 / \mathrm{m}^{2}\right)$ and A. patula $\left(3,4 / \mathrm{m}^{2}\right)$; and in the treatmen $\mathrm{F} 150$ are S. halepense $\left(15,8 / \mathrm{m}^{2}\right)$, S. nigrum $\left(6,9 / \mathrm{m}^{2}\right)$ and A. patula $\left(2,9 / \mathrm{m}^{2}\right)$ (tab. $\left.2,3,4\right)$. Although changes in the relative abundances of weeds caused differences in the community composition between plots without (C) and with different fertilizing regime (F50, F100 and F150), species composition was quite similar.

Additional remark considering floristic composition of sinousia is that up to this research $A$. patula and $K$. spuria were not consideres as troublesome agricultural weeds in Montenegro (Jovović, 1998; Stešević and Jovović, 2005; Caković et al., 2012).

\section{Life forms.}

The analysis of the total biological spectrum of the flora indicates the dominance of therophytes with $75.8 \%$, the most dominant of which were $\mathrm{T}$ scap terophytes (51.7\%). Hemicryptophytes contribute $17.2 \%$ to the biological 
spectrum, and geophytes (rhizomatous) 7\%. The spectrum of life forms fits into the general biological spectrum of the flora of Bjelopavlići plain (Caković et al., 2012). Considering the geographical position of this area and the environmental conditions that are under specific Mediterranean influence, and also bearing in mind that the use of cropping practices works in favour of the dominance of annual life forms (Armesto and Vidella, 1993), the predominance of therophytes in the biological spectrum is expected.

In the biological spectrum of vegetation participation of life forms is a bit different: annuals are dominant life form with 56,7 \%. They are followed by geophytes with $41,8 \%$ while hemicriptophytes participate the spectrum with 1,5 $\%$. In the different treatments the biological spectrum of vegetation did not show significant variation

\section{Weed density and weed cover.}

Primary role of the nutrients is to promote crop growth, but very often it also benefit weeds (Di Tomaso, 1995). In our experiment the average crop yield was highest in the F150 $(11.19 \pm 2.88 \mathrm{SD} \mathrm{kg} / \mathrm{plot})>\mathrm{F} 100(9.11 \pm 1.85 \mathrm{SD} \mathrm{kg} / \mathrm{plot})>$ F50 $(8.21 \pm 2.25 \mathrm{SD} \mathrm{kg} / \mathrm{plot})$, as well as total weediness F150 $(19.33 \%)>\mathrm{F} 100$ $(15.4 \%)>$ F50 $(14.8 \%)>\mathrm{C}(7 \%)$. Considering average weed density the decreasing order was a bit different F150 $\left(41.3 \mathrm{ind} / \mathrm{m}^{2}\right)>\mathrm{C}\left(36.9 \mathrm{ind} / \mathrm{m}^{2}\right)>\mathrm{F} 100$ (33.7 ind $\left./ \mathrm{m}^{2}\right)>\mathrm{F} 50\left(32.3 \mathrm{ind} / \mathrm{m}^{2}\right)$. It is explained with the fact that number of individuals and the cover are not obligatory in positive correlation. Size of individuals recorded at the control plot was significantly smaller comparing to the fertilized ones, thus the cover value was lower. However, analysing the species abundance, cover per single plot and crop yield in each regime of fertilization, some deviations are noticed (tab. 2, 3, 4), such as, in the plots No 10 (belongs to F100) and No 17 (belongs to F150) the total weed cover was 10\%. In eight plots which belongs to F50 the weed cover exceeded this value. Or the yield in plot 6 (belongs to F150) was rather low (6.95 kg). Due to the fact that such deviations is not possible to explain with biotic factors, such as competition between weed and crop, the answer migh be hidden in soil properties. Thus the future research should also include detailed soil analysis per each plot.

Nevertheless, when speaking about the weedeness degree of dominant species, following remarks are given. In the case of Sorghum halepense, it is shown that fertilizers increases the crop weediness, from $10.48 \mathrm{ind} / \mathrm{m}^{2}$ in the control, to $23.52 \mathrm{ind} / \mathrm{m}^{2}$ the treatment F50, to $121.72 \mathrm{ind} / \mathrm{m}^{2}$ was in the treatment 100 and $149.11 \mathrm{ind} / \mathrm{m}^{2}$ in the treatment F150 (tab. 2, 3, 4). Study of Dražić and Konstantinović (1996) showed the same regularlity, when nitrogen fertilizers are 
applied. Some other weeds from the sinousia like Amaranthus retroflexus, Portulaca oleracea, Polygonum aviculare, Setaria viridis etc. reacted the same way. This is also pointed out by Efthimiadoua et al. (2012) and Papastylianou et al. (2014). Opposite to this case, fertilizers can reduce crop weediness. Such case is reported for $K$. spuria (Salat et al. 2014). In our study treatment F50 caused rapid increase of weeding degree (from $2.10 \mathrm{ind} / \mathrm{m}^{2}$ in control to $37.40 \mathrm{ind} / \mathrm{m}^{2}$ ), while treatments F100 and F150 had opposite effects. The weedeness decreased from $35.74 \mathrm{ind} / \mathrm{m}^{2}$ in $\mathrm{F} 100$ to $19.14 \mathrm{ind} / \mathrm{m}^{2}$ in F150. It could be explained with the fact that F150 plots has bigger cover of aboveground part of the Swiss chard and taller weeds as $S$. nigrum and A. patula, thus the light conditions are infavorable for development of Kickxia spuria. Study of Lo Bianco (2007) and Puhui et al. (2011) pointed that fertilizing had no significant effect on plant biomass of either A. patula or $S$. nigrum. Our study did not show any clear pattern. In the case of $S$. nigrum, not even one induvidual was recorded on the control variant, while on F50 weeding degree was $23.53 \mathrm{ind} / \mathrm{m}^{2}$, on the F100 it was $4.38 \mathrm{ind} / \mathrm{m}^{2}$ and on the $\mathrm{F} 150$ it was $65.63 \mathrm{ind} / \mathrm{m}^{2}$. Weedeng degree of A. patula increased from 13.3 $\mathrm{ind} / \mathrm{m}^{2}$ in $\mathrm{C}$ to $18.10 \mathrm{ind} / \mathrm{m}^{2}$ in $\mathrm{F} 50$ to $32.09 \mathrm{ind} / \mathrm{m}^{2}$ in $\mathrm{F} 100$ and than decreased on $26.19 \mathrm{ind} / \mathrm{m}^{2}$ in $\mathrm{F} 150$.

Some studies shown that increase in the dose of fertilizer has positive effect on weed density, but negative on yield (Knežević et al., 2008). In our research increased doses of fertilizers had better effect on the crop yield than on weediness; this results inicated that swiss chard are better competitors for nutrients than are weed. As it is presented in table 4, the plots 16 and 17 had higher crop yield (16.05 kg and $15.05 \mathrm{~kg}$, respectively) compared to other plots with the same regime of fertilization (F150), and in the same time lower weed cover (12\% and $10 \%$, respectively). Soil analyses conducted before the fertilization have shown that plots 16 and 17 has higer content of humus and nitrogen in comparison to other plots with the same regime of fertilization (Kneževic et al., unpublished data). In such conditions, Swiss chard grows faster than weeds, thus it overcompetes them. Nevertheless, one plot in regime F150, the plot 6 had rather low yield of $6.95 \mathrm{~kg}$, but this can not be explained with better weed competitivity, while the weed cover was only12\%. However in this plot was recorded the lowest value of electical conductivity of soil, as a parameter of amount of salt in the soil, as well as relatively lower content of available macronutrients $\mathrm{P}$ and $\mathrm{K}$. As it is concluded before, the answer migh be hidden in soil properties, thus the future research should also include more detailed soil analysis per each plot. 


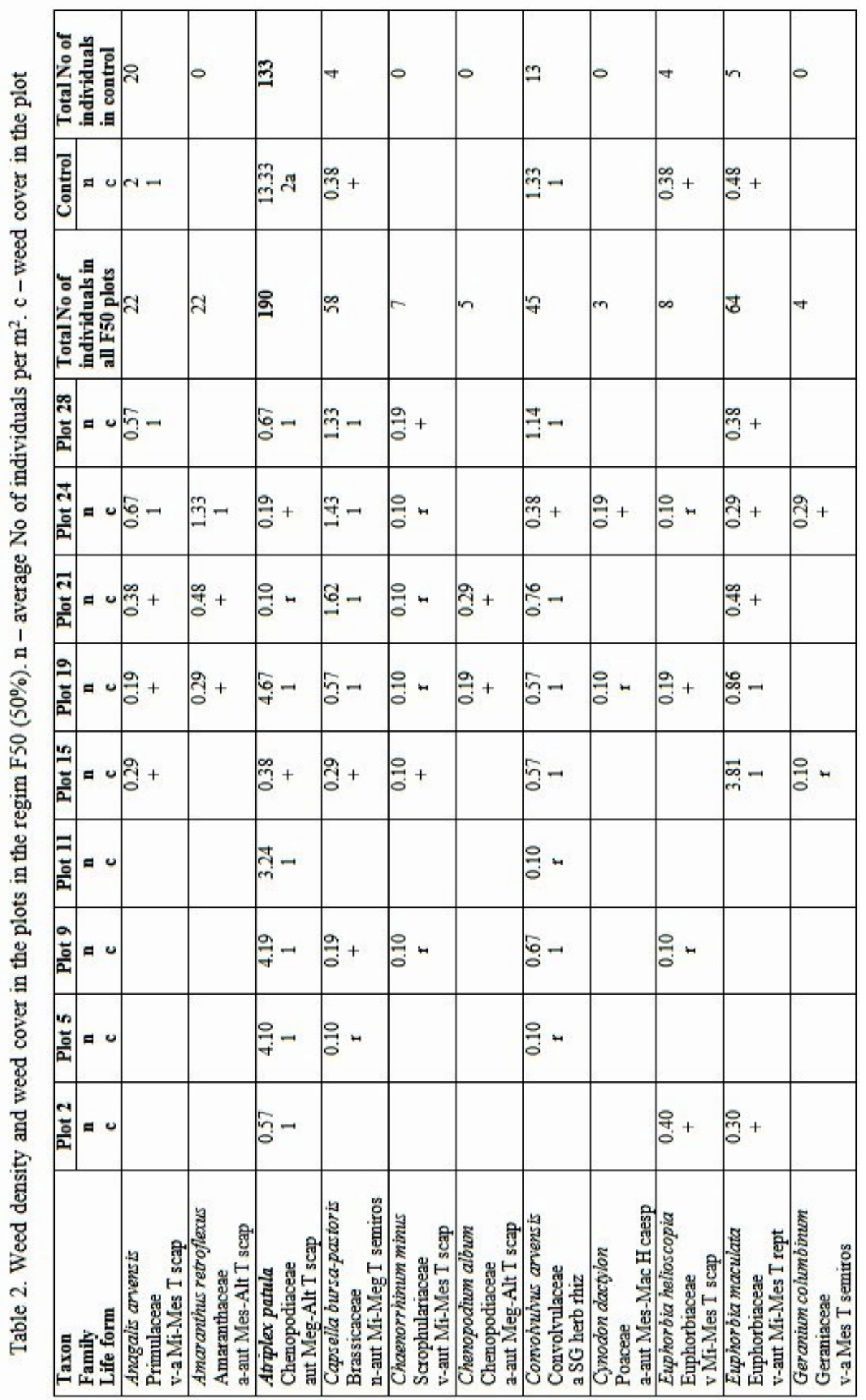


Cakovic et al.

\begin{tabular}{|c|c|c|c|c|c|c|c|c|c|c|c|}
\hline 形 & $\vec{m}$ & $\vec{\sim}$ & 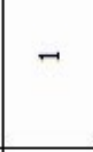 & 0 & $N$ & 0 & 0 & $\infty$ & 0 & 0 & $N$ \\
\hline : & $\underset{m}{\vec{H}}-$ & 극- & 응 - & & $\frac{9}{0}+$ & & & $\stackrel{\circ}{\circ}$ & & & $\frac{a}{0}+$ \\
\hline 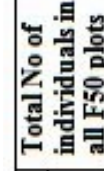 & ஜ & S' & : & F & 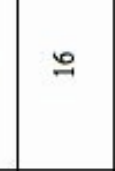 & t & 0 & สี & $\infty$ & a & సి \\
\hline 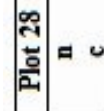 & $\frac{9}{0}+$ & รี- & & & & & & 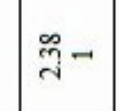 & సి & & $\stackrel{ \pm}{I}-$ \\
\hline$\left|\begin{array}{l}\vec{a} \\
\vdots \\
\vec{a} \\
\vec{a}\end{array}\right|=0$ & & $\underset{\sim}{\stackrel{n}{r}} \pi$ & & รี- & & 응- & & İ & & 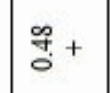 & $\frac{9}{0}+$ \\
\hline 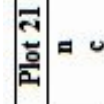 & & $\underset{\exists}{\exists} \pi$ & & 祭- & $\stackrel{9}{0}+$ & & & \pm- & & $\frac{9}{0}+$ & 옹 - \\
\hline$\left|\begin{array}{c}a \\
\vec{a}\end{array}\right|=0$ & శ్రి+ & $\frac{5}{+}-$ & & & ริ- & స్రి + & & '용- & & & \\
\hline$\stackrel{a}{a}$ & & ลิ- & & & స్ి + & & & $\frac{a}{\mathrm{j}}-$ & $\stackrel{9}{\circ}+$ & $\frac{9}{0}+$ & 융 - \\
\hline$\left|\begin{array}{l}\vec{a} \\
\vec{a}\end{array}\right|=0$ & ${ }_{\text {ç- }}^{6}-$ & รี- & & & & & & $\stackrel{ \pm}{I}-$ & & & 웅 - \\
\hline$\left|\begin{array}{l}a \\
\vec{a} \\
\vec{a}\end{array}\right|=0$ & $m_{m-1}^{m}$ & 哭+ & & & & & & $\stackrel{\text { g̊ }}{0}+$ & & & \\
\hline$\left|\begin{array}{c}\mid \infty \\
\frac{2}{2}\end{array}\right|=0$ & ন্ডి+ & 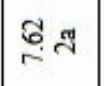 & & & & & & $\stackrel{\circ}{\circ}-$ & & & ถิ่ \\
\hline $\begin{array}{c}\frac{9}{2} \\
\frac{1}{2}\end{array}=$ & 융- & 筞+ & & 㝵- & $\stackrel{\infty}{0}+$ & & & \&్ & & & $\hat{n}^{2}+$ \\
\hline 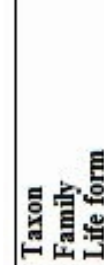 & 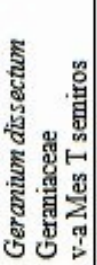 & 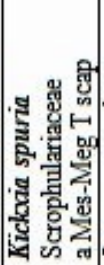 & 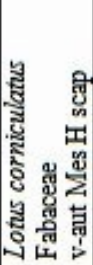 & 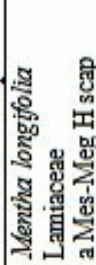 & 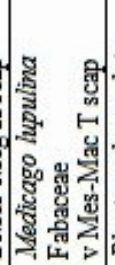 & 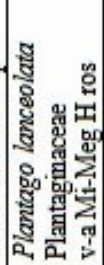 & : & 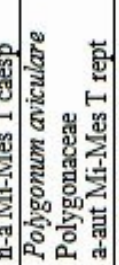 & 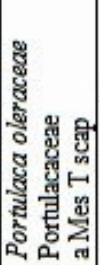 & 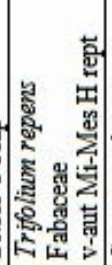 & 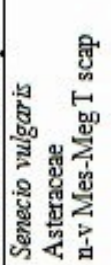 \\
\hline
\end{tabular}




\begin{tabular}{|c|c|c|c|c|c|c|c|c|c|c|}
\hline 氪娄 & 0 & 0 & 0 & 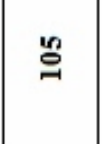 & $N$ & 0 & 9 & 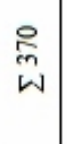 & & \\
\hline 帘 & & & & 导 & $\frac{9}{0}+$ & & 익- & m. & & $\begin{array}{l}2 \\
\dot{1} \\
+\end{array}$ \\
\hline 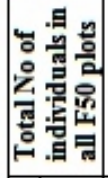 & a & $\frac{5}{4}$ & $\stackrel{\circ}{\leftrightarrows}$ & తี & $\rightarrow$ & ஊ & ஜ્ন & 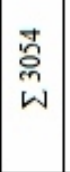 & & \\
\hline 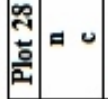 & ते + & 䑧 & & ปุ & 옹 & 守 + & $m_{m}$ & $\overrightarrow{\text { s. }}$ & $\approx \approx$ & 5 \\
\hline 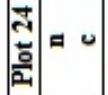 & ते + & 응- & กิ่ & mై & & 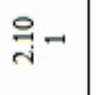 & กิ- & \begin{tabular}{|l|}
1 \\
2 \\
0 \\
0 \\
\multirow{2}{*}{}
\end{tabular} & $\vec{\nabla}=$ & '。 \\
\hline 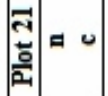 & तે + & $\underset{\text { min }}{ \pm}$ & तે + & हु่ & & $\frac{9}{\mathrm{i}}-$ & 윽- & in & 규 & '? \\
\hline 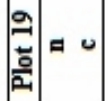 & & 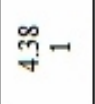 & $\stackrel{\infty}{\hat{0}}+$ & สี่ & & 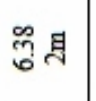 & ली & \begin{tabular}{l|} 
f \\
of \\
fo
\end{tabular} & $a$ & $\stackrel{\infty}{\infty}$ \\
\hline 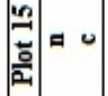 & & 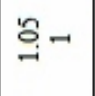 & ते + & $\vec{r}$ 具 & & त्ञ & $\stackrel{\infty}{\infty}-$ & 今̊ & $\approx=$ & 哭 \\
\hline \begin{tabular}{|l|l}
$=$ \\
\\
$\mathbf{2}$
\end{tabular} \mid$=0$ & & & & 6용 & & & స్ల - & ô & $\infty$ 으 & $\stackrel{2}{\stackrel{8}{*}}$ \\
\hline 高 & & & & 응겨 & & & \$ㄱ- & 2 & $=\approx$ & 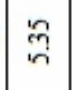 \\
\hline 高 & & & & 6욤 & & & $\overline{0}_{0}+$ & \begin{tabular}{l|}
8 \\
ते
\end{tabular} & $0 \approx$ & ถู \\
\hline 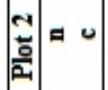 & & & & กี่ & & & ㅇ- & 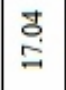 & $\exists \approx$ & 'ू \\
\hline 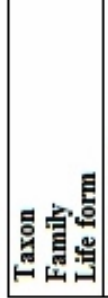 & 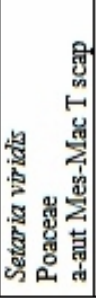 & 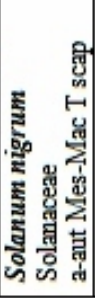 & 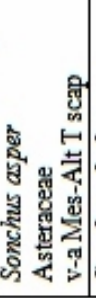 & 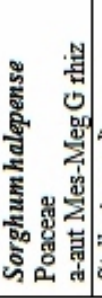 & 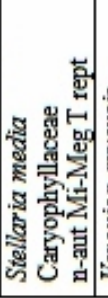 & 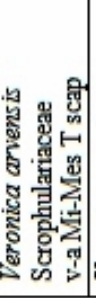 & 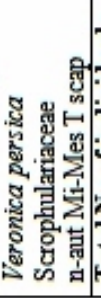 & 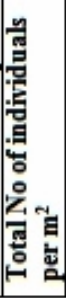 & 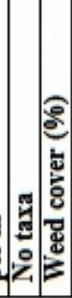 & 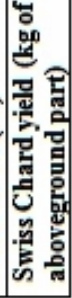 \\
\hline
\end{tabular}




\begin{tabular}{|c|c|c|c|c|c|c|c|c|c|c|c|c|}
\hline & 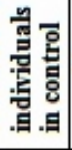 & & 0 & $\approx$ & $t$ & 0 & 0 & $\cong$ & 0 & 寸 & in & 0 \\
\hline ن & a 0 & $n \rightarrow$ & & ma & $\infty_{n}^{\infty}+$ & & & $\stackrel{m}{-}-$ & & $\tilde{m}^{\infty}+$ & 导 + & \\
\hline 尊 & 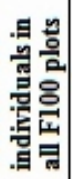 & & in & శ్లి & ম & $m$ & 으 & $\infty$ & 0 & n & a & $\approx$ \\
\hline 을 & a & $b_{0}+$ & & $\ddot{0}+$ & 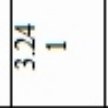 & & & $\frac{0}{2}-$ & & $\frac{9}{0}+$ & $\frac{0}{0}$ & $\frac{0}{0}$ \\
\hline 胥 & a & 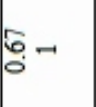 & & 导 + & $\stackrel{\mathrm{b}}{\mathrm{i}}-$ & 응 - & $\frac{a}{0}+$ & $\frac{0}{2}-$ & & $\overbrace{}^{\infty}+$ & శ్రి + & \\
\hline 월 & a & हे + & 尽貝 & तु- & है- & 음 - & & हn- & & & 궁 + & $\frac{0}{0}$ - \\
\hline 홀 & $\approx 0$ & & & कृ & $\overbrace{0}^{\infty}$ & 응 - & & 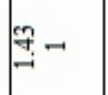 & & & స్ㅇ + & $\frac{0}{6}$ \\
\hline 웜 & a 0 & & & సू. & శి + & & है- & $\because-$ & & & & \\
\hline 흠 & $=0$ & & & 声- & 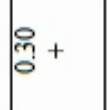 & & & $\frac{9}{0}+$ & & & & \\
\hline 물 & $\approx 0$ & & & 음- & ?ृ? + & & & in- & & & & \\
\hline 을 & a 0 & & & 그- & ల్ + & & & $\stackrel{ \pm}{-}$ & & & & $\stackrel{-}{B}$ \\
\hline 흘 & $=0$ & & & क- & 荘 + & & 色+ & $\stackrel{2}{-}$ & & & & 音- \\
\hline & 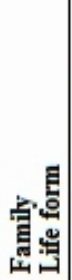 & 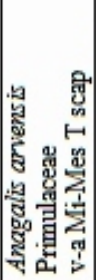 & 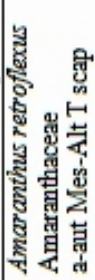 & 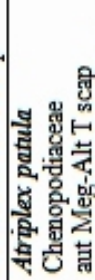 & 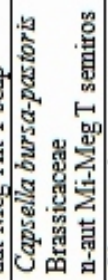 & 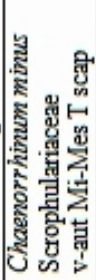 & 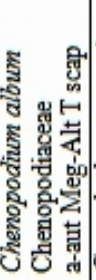 & 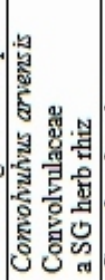 & 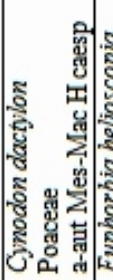 & 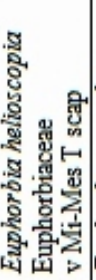 & 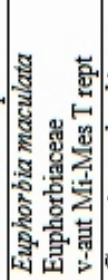 & 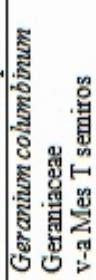 \\
\hline
\end{tabular}




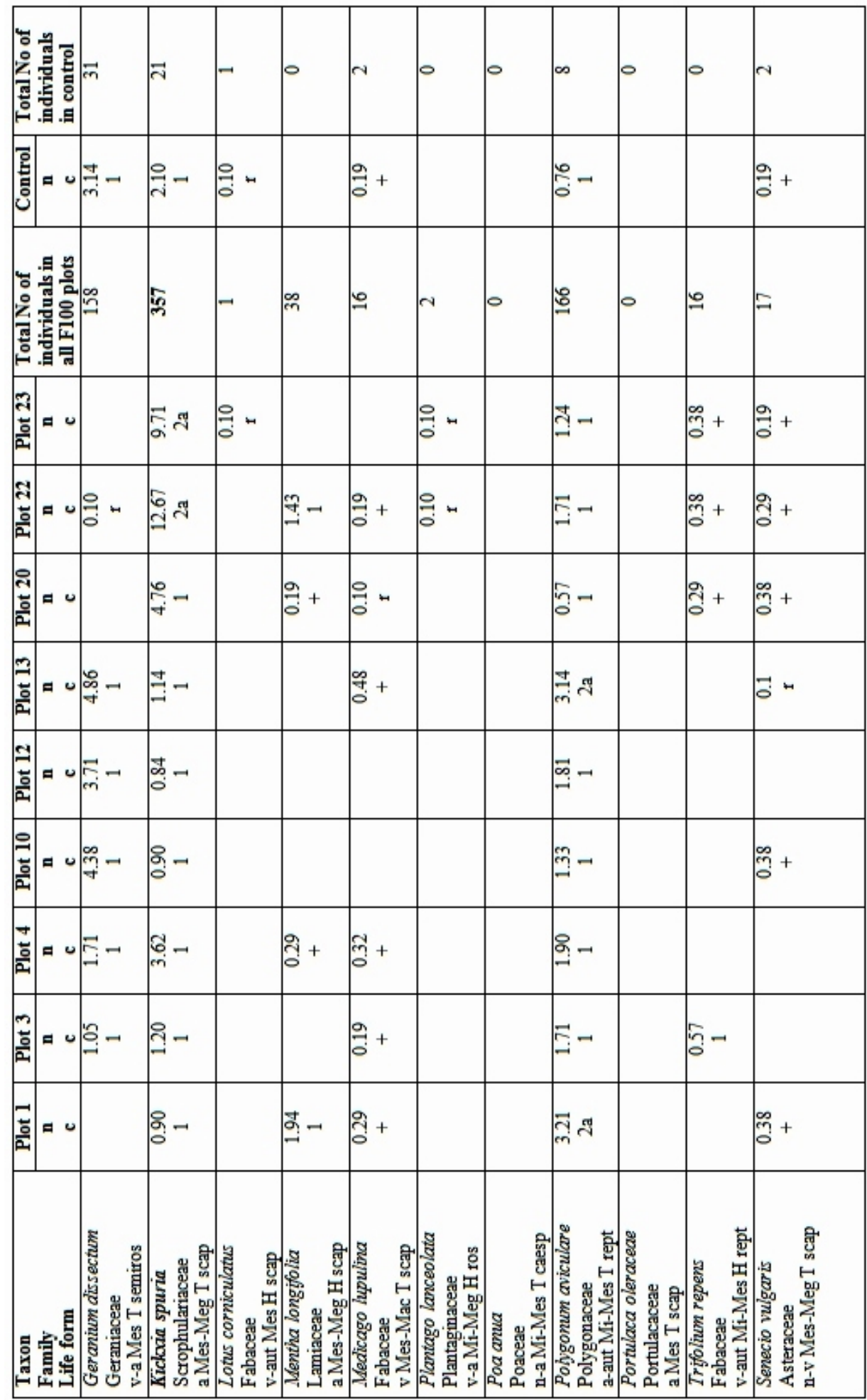




\begin{tabular}{|c|c|c|c|c|c|c|c|c|}
\hline 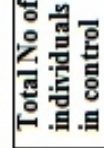 & & 0 & 0 & $\ddot{g}$ & $\sim$ & & $\because \quad \begin{array}{lll}0 \\
0\end{array}$ & \\
\hline$=$ & & & & $\underbrace{\infty}_{0}$ & $\frac{9}{0}+$ & & 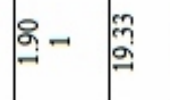 & 'b \\
\hline 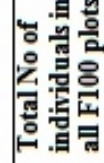 & & 7 & $\nexists$ & 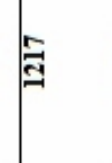 & 0 & స్ స్ & 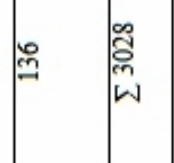 & \\
\hline$\left|\begin{array}{l}a \\
\frac{a}{2} \\
\frac{a}{2}\end{array}\right|=0$ & 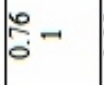 & $\hat{b}-$ & $I_{-1}$ & ลี & & 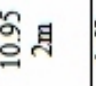 & 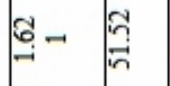 & $\therefore \approx \omega_{\infty}$ \\
\hline$\left|\begin{array}{c}\pi \\
\frac{1}{2} \\
\frac{1}{2}\end{array}\right|=0$ & & $\mid$ & $\frac{9}{0}+$ & مित & & กี & हn- & ㅊํำ \\
\hline$\left|\begin{array}{l}0 \\
\frac{a}{2} \\
\frac{0}{2}\end{array}\right|=0$ & & $\hat{\mathrm{n}}-$ & $2+$ & חู & & & $-\infty$ & 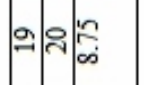 \\
\hline $\mid \frac{3}{\frac{a}{2}}$ & & & & 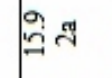 & कి- & & $\overrightarrow{7}$ & $=\hat{c}$ \\
\hline $\mid=$ & & & & $\int_{\infty}^{8} \pi$ & & & $-\frac{7}{2}$ & مै \\
\hline$\left|\begin{array}{l}0 \\
\frac{0}{2} \\
\frac{1}{2}\end{array}\right|=0$ & & & & \%目 & & & $\mid$ & \\
\hline 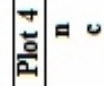 & & & & $\hat{\sigma}_{0} \pi$ & & & $\ddot{\ddot{0}+}$ & \\
\hline$=0$ & & & & กิก & & $\frac{9}{0}$ - & $\stackrel{2}{2}$ & \\
\hline$=0$ & & & & స్తి & हृ & त్ & 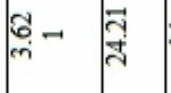 & $\pm=\left[\begin{array}{l}n \\
? \\
\varrho\end{array}\right.$ \\
\hline 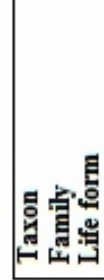 & 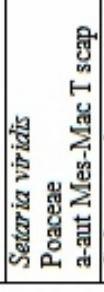 & 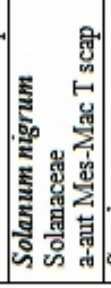 & 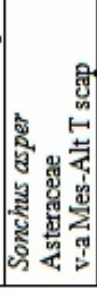 & 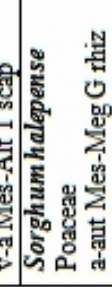 & 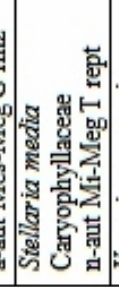 & 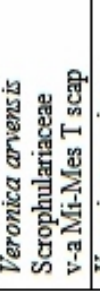 & 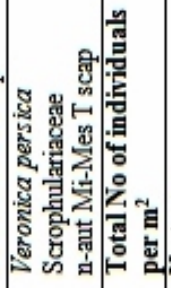 & | \\
\hline
\end{tabular}




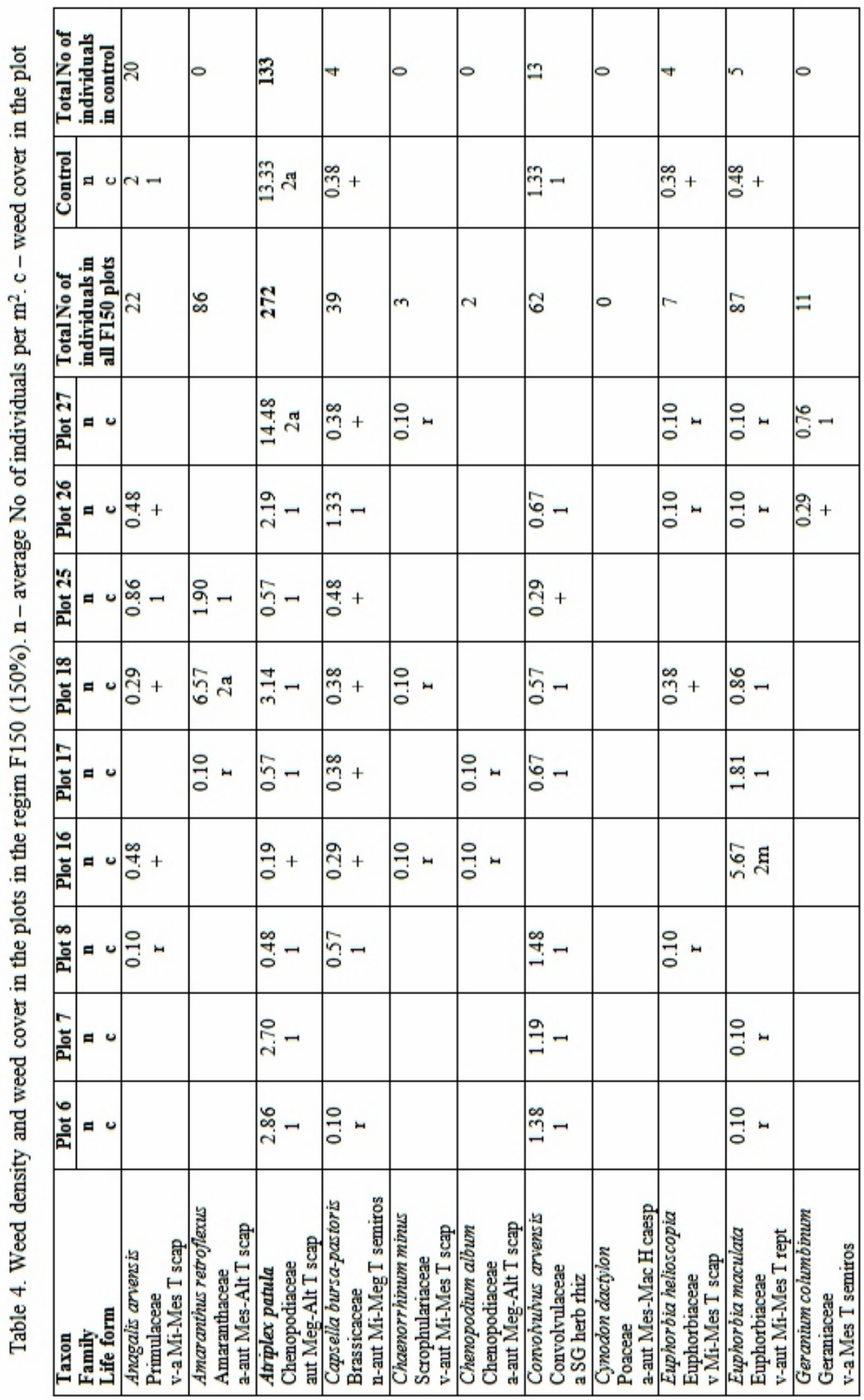




\begin{tabular}{|c|c|c|c|c|c|c|c|c|c|c|c|c|}
\hline & 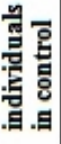 & $\vec{m}$ & $\vec{\sim}$ & $\rightarrow$ & 0 & $N$ & 0 & 0 & $\infty$ & 0 & 0 & N \\
\hline 홍 & $\Rightarrow 0$ & 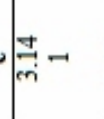 & 을- & 응 - & & $\frac{a}{0}+$ & & & $\frac{0}{2}-$ & & & $\frac{9}{0}+$ \\
\hline 突 & 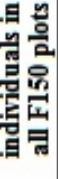 & \pm & a & 0 & $\infty$ & $\infty$ & - & $\rightarrow$ & 옥 & 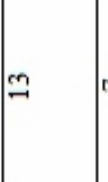 & N & $\approx$ \\
\hline 촌 & $=0$ & 舟 & & & & & & & & $\stackrel{6}{6}-$ & $\frac{9}{7}+$ & 高- \\
\hline : & $\Rightarrow 0$ & & 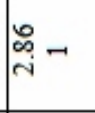 & & & & & & $\frac{a}{\mathrm{i}}-$ & $\begin{array}{c}\infty \\
m \\
0\end{array}+$ & $\overbrace{0}^{\infty}+$ & 导+ \\
\hline 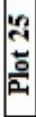 & $=0$ & $m_{0}^{\infty}+$ & 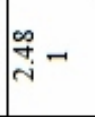 & & $m_{0}^{\infty}+$ & & & & तై & & & $\frac{9}{0}+$ \\
\hline 番 & $=0$ & & în & & & $m_{0}^{\infty}+$ & 음 & & $\dddot{m}-$ & & & $\frac{0}{6}$ - \\
\hline 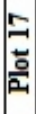 & $\approx 0$ & $\frac{9}{0}+$ & तु- & & & స్ి + & & & ర্- & స̂े + & సి + & సి \\
\hline 훔 & $\approx 0$ & & 윽 - & & & in - & & & ন্ণী - & $\overbrace{0}^{\infty}+$ & & \\
\hline 竞 & $=0$ & 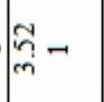 & & & & $\stackrel{\infty}{\infty}_{0}^{\infty}+$ & & & शे- & & & $\frac{9}{0}+$ \\
\hline 훌 & $\approx 0$ & & ก๊ & 으- & & & $\overbrace{0}^{\infty}+$ & & & 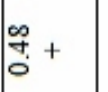 & & \\
\hline 递 & $=0$ & $\vec{\infty}-$ & 2 & & 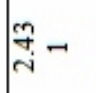 & 웅- & & 음 & กิ- & & & 응 \\
\hline & 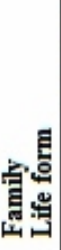 & 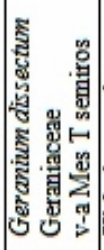 & 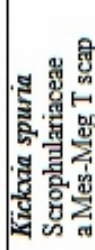 & 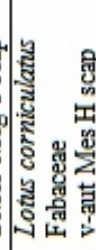 & 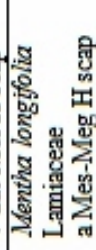 & 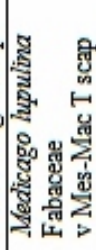 & 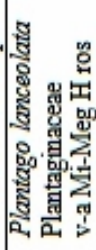 & (1) & 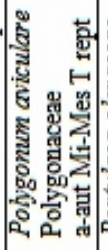 & 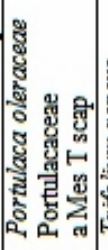 & 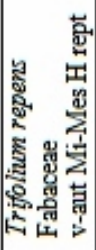 & 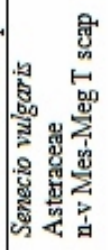 \\
\hline
\end{tabular}




\begin{tabular}{|c|c|c|c|c|c|c|c|c|c|c|c|c|}
\hline & 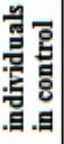 & 0 & 0 & 0 & $\stackrel{\varrho}{\varrho}$ & N & 0 & I & 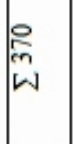 & & & \\
\hline 홍 & $\Rightarrow 0$ & & & & 染 & $\frac{9}{3}+$ & & \% - & @2 & $\cong$ & & 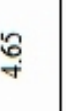 \\
\hline & 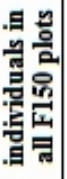 & & గొ & $\stackrel{-}{-}$ & aี & ब & ลิ & $\vec{\Phi}$ & $\begin{array}{c}n \\
\sum_{n} \\
\text { nn } \\
W\end{array}$ & & & \\
\hline 형 & $=0$ & $\overbrace{0}^{\infty}+$ & م્ન & $\overbrace{0}^{\infty}+$ & 赵 & & 음 & $\stackrel{\infty}{m}-$ & \begin{tabular}{l}
$\infty$ \\
$\infty$ \\
$\vdots$ \\
\hdashline
\end{tabular} & $\because$ & & $\stackrel{n}{a}$ \\
\hline 迹 & $\begin{array}{llll}a & 0\end{array}$ & & ma & 落 & ڤિ. & & $\vec{\infty}-$ & 吕- & in & $\Xi$ & & ڤે \\
\hline 告 & $\begin{array}{lll}a & 0\end{array}$ & & 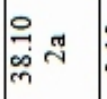 & 을 - & $\infty$ & & तે - & $m_{n}^{\infty}-$ & तु่ & $\cong$ & & 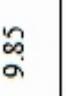 \\
\hline$\frac{\infty}{2}$ & $\begin{array}{llll}a & 0\end{array}$ & & 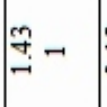 & $\frac{9}{3}+$ & 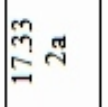 & & 중 & $\stackrel{n}{\circ}-$ & 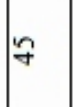 & 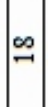 & & "ñ \\
\hline 言 & $\begin{array}{lll}a & 0\end{array}$ & & @- & 음 & $\beth_{\beth}^{ \pm}$ & & 舲 & $\stackrel{-}{\circ}$ & à & $\infty$ & & 参 \\
\hline$\frac{5}{\text { 움 }}$ & $\begin{array}{lll}a & 0\end{array}$ & & సે + & & 욤 & & 음 & 을 - & $\frac{0}{m}$ & \pm & & 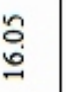 \\
\hline 冓 & $\begin{array}{lll}a & 0\end{array}$ & & & & ల్లి & 응 & পి- & @ి- & $\begin{array}{l}\infty \\
\infty \\
\infty \\
N\end{array}$ & $\cong$ & & gू \\
\hline$\frac{\mathrm{a}}{2}$ & $\Rightarrow 0$ & & & & 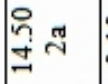 & 응 & $\stackrel{-}{\circ}$ & 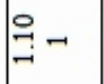 & $\vec{N}$ & $=$ & & $\begin{array}{l}0 \\
\infty \\
0 \\
0\end{array}$ \\
\hline 흠 & $\begin{array}{lll}a & 0\end{array}$ & & गे + & & חூָ & $\frac{9}{0}+$ & & 을- & 아 & $\because$ & & ڤ్ \\
\hline & 窗悬 & 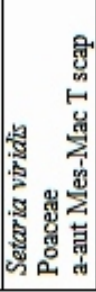 & 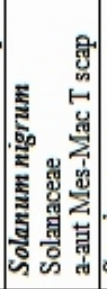 & 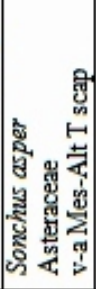 & 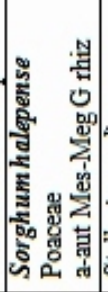 & 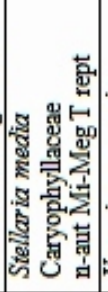 & 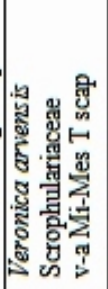 & 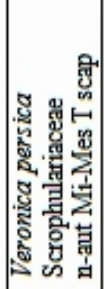 & 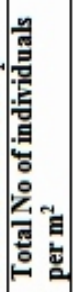 & 骂 & . & 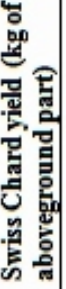 \\
\hline
\end{tabular}


Analysis of the crop yield and weed cover in the plots wih regime of fertilization F50 shown similar results. Among the plots with fertilization regime F50 the highest yield was recorded in the plot 15 (12.05 kg) (table 2), where the content of humus was highest (table 1) and weed cover exceeded the average value for this regime of fertilization (17\%). On the other hand, in the plot 11 (table 2) the yield was minimal (4.75 kg ) and weed cover was the lowest (10\%). Considering regime F100 (table 3), the highest yield was recorded in the plot 3 (12.45 kg), but, unlike other regimes (F150 and F50), the plot with highest yield didn't have highest content of humus in the soil before the treatment (table 1). The highest humus content is reported for plot 10 (table 1), but the plot had lower crop yield (8.85 kg) and the lowest weed cover (10\%) (table 3). This can be explained, as mentioned above, especially by the content of available potassium as well as soil EC which frequently positively correlated to crop yield. Thus, Knežević et al. (2014) found that the yield of Swiss chard was in positive significant relationship with available soil K. Namely, in soil of the plot 3 the highest content of available $\mathrm{K}$ and EC value were measured, but soil of the plot 10 had relatively lower content of $\mathrm{K}$ and $\mathrm{EC}$ value.

It is known that long term use of fertilizers changes the agroecological conditions for existance of the whole agrophytocoenosis and its separate components (Atanasova et al., 2009), thus our future investigations will be focused on this topic.

\section{CONCLUSIONS}

Weed sinousia of Swiss chard in Montenegro consists of 29 species, out of 26 genera and 17 families and in taxonomic spectrum it differes from the sinousia of other crops investigated in Montenegro. Dominant families in the specrum are Poaceae, Scrophulariaceae (4 species each) and Fabaceae (3 species). The most abundant species in sinousia are S. halepense, S. nigrum, K. spuria and A. patula. Up to this research A. patula and K. spuria was not consideres as troublesome agricultural weed in Montenegro. In the total weediness dominant weed species participate with $67.3 \%$. Ranking of dominant species differs between the treatments, but athough changes in the relative abundances of weeds caused differences in the community composition between plots without (C) and with different fertilizing regime (F50, F100 and F150), species composition was quite similar.

The analysis of the total biological spectrum indicates the dominance of therophytes with $75.8 \%$, while hemicryptophytes contribute the spectrum with $17.2 \%$. Such spectrum of life forms fits into the general biological spectrum of the flora of Bjelopavlići plain.

Considering the effect of fertilizers on the crop growth and weediness general conclusion is that fertilizers benefit both the crop and weeds. The average crop yield was highest in the regime F150, as well as total weediness F150. Nevertheless our research has shown that increased doses of fertilizers had better effect on the crop yield than on weediness. However, analysing the species 
abundance, cover per single plot and crop yield in each regime of fertilization, some deviations are noticed, but in order to find proped explainations additional research are needed.

\section{ACKNOWLEDGEMENTS}

This work has been supported by the Ministry of Science of Montenegro project „INGAF“ and the HERIC project through the BIO-ICT Centre of Excellence (Contract No. 01-1001).

\section{REFERENCES}

Armesto, J.J. \& Vidella, P.E. (1993): Plant life-forms and biogeographic relations of the flora of Lagunilles in the fug-free Pacific coastal desert. -Annales of the Missouri botanical garden, 80(2): 499-511.

Atanasova, D., Koteva, V. \& Marcheva, M. (2009): Weed infestation in long-term field trial with different levels of fertilization -44th Croatian \& 4th International Symposium on Agriculture, available online: http://sa.agr.hr/pdf/2009/sa2009_p0503.pdf (access 30.01.2015)

Barkman, J.J., Doing, H. \& Segal, S. (1964): Kritische Bemerkungen und Vorschlage zur quantitativen Vegetationsanalyse. - Acta botanica Neerlandica, 13: 394-419.

Blackshaw, R.E., Brandt, R.N., Janzen, H.H., Entz, T., Grant, C.A. \& Derksen, D.A. (2003): Differential response of weed species to added nitrogen. - Weed Science, 51: 532-539.

Bolkenta, Ş., Yanardağb, R., Tabakoğlu-Oğuza, A. \& Özsoy-Saçanb, Ö. (2000): Effects of chard (Beta vulgaris L. var.cicla) extract on pancreatic B cells in streptozotocindiabetic rats: a morphological and biochemical study. - Journal of Ethnopharmacology, 73(1-2): 251-259.

Caković, D., Stešević, D., Iković, V., Knežević, M. \& Latinović, N. (2012): Contribution to the knowledge of weed flora of Bjelopavlići plain. - Agriculture \& Forestry, Podgorica, 58(4): 25-41.

Dhima, R.V. \& Eleftherohorinos, I.G. (2001): Influence of nitrogen on competition winter cereals and sterile oat. - Weed Science, 49: 77-82.

Di Tomaso, J.M. (1995): Approacehs for improving crop competitivness through manipulation of fertilization strategies. - Weed Science, 43: 492-497.

Domac, R. (1994): Mala flora Hrvatske i susjednih područja. Zagreb, - Školska knjiga, 503 pp.

Dražić, D. \& Konstantinović, B. (1996): Divlji sirak i njegovo suzbijanje. Poljoknjiga, Beograd, 95 pp.

Dusky, J.A., Shrefler, J.W., Shilling, D.G., Brecke, B.J., Colvin, D.L., Sanchez, C.A. \& Stall, W.M. (1996): Influence of phosphorus fertility on competition between lettuce and Amaranthus spinosus L. Proc. 2th Intl'. Weed Control Congress, Department of Weed Control and Pesticide Ecology, Denmark, 141-145.

Efthimiadoua, A., Froud-Williamsb, R.J., Eleftherohorinos, I, Karkanisd, A. \& Bilalis, D.J. (2012): Effects of organic and inorganic amendments on weed management in sweet maize. -International Journal of Plant Production, 6(3): 291-308.

Ellenberg, H. \& Muller-Dombois, D. (1967): A key to Raunkiaer plant life forms with revised subdivisions. Berichte des Geobotanisches Institut ETH Stiftung Rübel, Zürich, 37: 56-73.

Gil M.I., Ferreres F. \& Tomas-Barberan F.A. (1998): Effect of modified atmosphere packaging on the flavonoids and vitamin C content of minimally processed Swiss chard (Beta vulgaris ssp. cicla). - Journal of Agriculture and Food Chemistry, 46: 2007-2012. 
Jovović, Z. (1998): The effect of herbicides upon the numbers and biomass of weeds in agropohytocenosis of coen (Zea mays). - Agriculture and forestry, Podgorica, 44(3-4): 5-19.

Knežević, D., Avramović, S. \& Branković, G. (2008): Korovska sinuzija u usevu pšenice i uticaj na prinos zrna u različitom režimu ishrane. - Acta Herbologica, Beograd, 17(2): $95-103$.

Knežević, M., Đurović, D., Mugoša, B., Strunjaš, M. \& Topalović, A. (2014): Relationships between parameters of soil and chard (Beta vulgaris L. var. cicla L.). - Agriculture and Forestry, Podgorica, 60(3): 275-283.

Knežević, M., Đurović, D., Mugoša, B., Strunjaš, M. \& Topalović, A. (2014): Unpublished data from study of the effect of irrigation and fertilization on antioxidant activity and phenolic content of fruits.

Liebman, M., Mohler, C.L. (2001): Weeds and the soil environment. In: M. Liebman, C.L. Mohler \& C.P. Staver, (Eds) (2001): Ecological Management of Agricultural Weeds. Cambridge University Press, Cambridge, London, pp: 210-268.

Lo Bianco, R. (2007): Root topology and allocation patterns of Atriplex patula seedlings supplied with different nutrient concentrations.- Italian Journal of Agrometeorology, Florence, 35(2): 35-39.

Malý I., Baroš J., Hlušek J., Kopec K., Petř́ková K., Rod J. \& Spitz P. (1998): Polní zelinářství. - Agrospoj, Praha: 175-185.

Miceli, A. \& Miceli, C. (2001): Effect of Nitrogen Fertilization on the Quality of Swiss chard at Harvest and During Storage as Minimally Processed Produce. - Journal of Foof Quality, 37: 125-134.

Pokluda, R. \& Kuben, J. (2002): Comparison of selected Swiss chard (Beta vulgaris ssp. cicla L.) varieties. - Scientia Horticulturae, 29 (3): 114-118.

Papastylianou, P., Kakabouki, I., Tsiplakou, E., Travlos, I., Bilalis, D., Hela, D., Chachalis, Anogiatis, D., \& Gzervas, G. (2014): Effect of fertilization on yield and quality of biomass of quinoa (Chenopodium quinoa Willd.) and green amaranth (Amaranthus retroflexus L.). - Bulletin of University of Agricultural Sciences and Veterinary Medicine Cluj-Napoca, Horticulture, 71(2): 299-292.

Puhui, J, Tieheng, S., Yufang, S., Leigh Ackland, M. \& Yang, L. (2011): Strategies for enhancing the phytoremediation of cadmium-contaminatedagricultural soils by Solanum nigrum L. - Environmental Pollution, 159: 762-768.

Salat, A., Armengot, L., Sans, X. \& Blanco-Moreno, J.M. (2014): Short-term effects of crop husbandry on the weed communityof a cereal-legume rotation. In: Rahmann, G. \& Aksoy, U. (Eds), Proceedings of the 4th ISOFAR Scientific Conference.'Building Organic Bridges’, at the Organic World Congress 2014, 13-15 Oct., Istanbul, Turkey.

Santamaria, P., Elia, A., Serio, F., Gonella, M. \& Parente, A. (1999a): Comparison between nitrate and ammonium nutrition in fennel, celery and Swiss chard. - Journal of Plant Nutrition, 22: 1091-1106.

Santamaria, P., Elia, A., Serio, F. \& Todaro, E. (1999b): A survey of nitrate and oxalate content in fresh vegetables. - Journal of the Science of Food and Agriculture, 79: 1882-1888.

Santos, B., Dusky, J.A., Stall, W.M., Shilling, D.G. \& Bewick, T.A. (1998): Phosphorous effects on competitive interactions of smooth pigweed (Amaranthous hybridus) and common purslane (Portulaca oleracea) with lettuce. - Weed Science, 46: 307-312.

Shannon, M.C., Grieve, C.M., Lesch, S.M. \& Draper, J.H. (2000): Analysis of salt tolerance in nine leafy vegetables irrigated with saline drainage water. - Journal of the American Society for Horticultural Science,125: 658-664.

Smith, D.C., Beharee, V. \& Hughes, J.C. (2001): The effects of composts produce by simple composting procedure on the yields of swiss chard (Beta vulgaris L. var. flavescens) 
and common bean (Phaseolus vulgaris L. var. nanus). - Scientia Horticulturae, 91: 393-406.

Stešević, D. \& Jovović, Z. (2005): Dominant weed species of potato crop in mountaincontinental part of Montenegro. - Pakistan Journal of Weed Science Research, 10(3-4): 169-174.

Stevanović, V. (1992): Klasifikacija životnih formi. In: Sarić, M.R. (ed.): Flora Srbije 1. Srpska akademija nauka i umetnosti, Beograd. pp: 47-56. 